\title{
Spółdzielczość jako forma integracji środowisk gospodarczych (perspektywa prawna)
}

\section{Cooperation as a Form of Integration of Economic Circles (Legal Point of View)}

\begin{abstract}
Streszczenie: Ideą artykułu jest realizacja celu poznawczego, którym jest zbadanie, czy w Ustawie $z$ dnia 16 września 1982 r. Prawo spółdzielcze (tekst jednolity: Dz.U. z 2018 r., poz. 1285 z późn. zm.) znajdują się rozwiązania prawne sprzyjające integracji środowisk gospodarczych przez spółdzielczość, oraz celu praktycznego, zmierzającego do sformułowania pod adresem prawodawcy postulatów dotyczących spółdzielczości. Hipoteza badawcza artykułu stanowi, że wspomniana wyżej ustawa zawiera rozwiązania prawne sprzyjające integracji środowisk gospodarczych przez spółdzielczość, choć rozwiązania te posiadają luki ustawodawcze. Zastosowana metoda badawcza to metoda dogmatyczna. Przeprowadzone badania pozwalają stwierdzić, że spółdzielczość jest formą prawną integrującą środowiska gospodarcze. Realizacja celu poznawczego nasunęła określone wnioski. Przede wszystkim, odrębne kategorie spółdzielni pomagają w integracji różnych środowisk gospodarczych. Ponadto organizacja organów spółdzielni sprzyja integracji ich członków. Co więcej, elementem integrującym środowiska gospodarcze jest działalność związków spółdzielczych i samorządu spółdzielczego. Z kolei realizacja celu praktycznego pozwoliła sformułować postulaty dotyczące polityki ustawodawczej w zakresie spółdzielczości. Przede wszystkim należy stworzyć więcej kategorii spółdzielni w celu integracji kolejnych środowisk gospodarczych. Ponadto, należy zmodyfikować funkcjonowanie organów spółdzielni w taki sposób, aby lepiej uwzględniać w uchwałach interes wszystkich członków spółdzielni. Realizacja celów artykułu potwierdziła słuszność hipotezy badawczej.
\end{abstract}

Abstract: The idea of the article is realisation of a cognitive goal which consists in examining whether there are legal solutions favouring the integration of economic circles by cooperation in the Cooperative Act of September 16, 1982 (consolidated text: Journal of Laws of 2018 item 1285 with later amendments), and a practical goal aiming at formulating postulates for the lawmaker referring to cooperation. The research hypothesis of the article ascertains that the above-mentioned act contains legal solutions favouring the integration of economic circles by cooperation, though these solutions have legislative gaps. The applied research method is a dogmatic method. Realised examination allows to ascertain that cooperation is the legal form integrating economic circles. Realisation of the cognitive goal brought definite conclusions. First of all, separate categories of cooperatives help in the integration of various 
economic circles. Moreover, organisation of bodies of cooperative favours integration of their members. What is more, the element which integrates economic circles is the activity of cooperative associations and cooperative self-government. Whereas, realisation of the practical goal allowed to formulate postulates referring to legislative policy in the field of cooperation. First of all, one should create more categories of cooperatives in order to integrate additional economic circles. Moreover, one ought to modify the functioning of cooperative's bodies in such a way as to take into consideration the interest of all the cooperative's members in resolutions. Realisation of the goals confirmed the research hypothesis.

Słowa kluczowe: działalność gospodarcza; integracja; spółdzielnia; środowisko gospodarcze

Keywords: business activity; cooperative; economic environment; integration

Otrzymano: 31 maja 2019

Received: 31 May 2019

Zaakceptowano: 10 września 2019

Accepted: 10 September 2019

\section{Sugerowana cytacja/Suggested citation:}

Woroniecki, P.M. (2019). Spółdzielczość jako forma integracji środowisk gospodarczych (perspektywa prawna). Przedsiębiorczość - Edukacja [Entrepreneurship - Education], 15(2), 264-276. doi: $10.24917 / 20833296.152 .18$

\section{Wstęp}

Spółdzielczość jest zagadnieniem szeroko analizowanym w literaturze naukowej, zwłaszcza prawniczej, ekonomicznej i socjologicznej. Trudno się temu dziwić, biorąc pod uwagę różnorodność i wagę funkcji, które spółdzielczość pełni w życiu gospodarczym społeczeństw i państw. Dla uniknięcia nieporozumień związanych z dość szerokim ujmowaniem pojęć, takich jak spółdzielczość czy spółdzielnia w obszarze różnych dziedzin nauki, należy doprecyzować, że $\mathrm{w}$ tym artykule pojęcie spółdzielni będzie rozumiane zgodnie $\mathrm{z}$ art. $1 \S 1$ Ustawy $z$ dnia 16 września 1982 r. Prawo spółdzielcze (tekst jednolity: Dz.U. z 2018 r., poz. 1285 z późn. zm.), który to przepis w sposób następujący objaśnia ten termin: „Spółdzielnia jest dobrowolnym zrzeszeniem nieograniczonej liczby osób, o zmiennym składzie osobowym i zmiennym funduszu udziałowym, które w interesie swoich członków prowadzi wspólną działalność gospodarczą". I dalej, w art. $1 \$ 2$ rzeczonej ustawy, ustawodawca zadeklarował, że spółdzielnie mogą „prowadzić działalność społeczną i oświatowo-kulturalną na rzecz swoich członków i ich środowiska”. Trafnie podkreśla się, że spółdzielnia nie jest zobligowana do realizacji działań społeczno-wychowawczych, wskazując że o tym decyduje sama spółdzielnia (Kuniewicz, 1995: 26).

Należy jeszcze wyjaśnić, że występujące w tym opracowaniu pojęcie środowiska gospodarczego zostało użyte w znaczeniu ogólnym, jako pewien krąg podmiotów zajmujących się podobnym rodzajem aktywności - naturalnie zgodnej z prawem - ukierunkowanej na zdobycie środków utrzymania. Natomiast pojęcia tego nie należy bezpośrednio wiązać z normatywną definicją działalności gospodarczej, zamieszczoną w art. 3 Ustawy $z$ dnia 6 marca 2018 r. Prawo przedsiębiorców (Dz.U. z 2019 r., poz. 1292), który to przepis stanowi, że działalność gospodarcza to „zorganizowana działalność zarobkowa, wykonywana we własnym imieniu i w sposób ciągły”. Takie podejście jest uzasadnione, bowiem pozwala spojrzeć z szerzej perspektywy na spółdzielnie jako podmioty działające w kierunku integracji najróżniejszych środowisk gospodarczych. 
Podstawowym celem poznawczym niniejszego opracowania jest zbadanie, czy polski prawodawca - konstruując przepisy ustawy Prawo spółdzielcze - wprowadził do nich rozwiązania prawne umożliwiające potraktowanie spółdzielczości jako prawnej struktury rzeczywiście sprzyjającej integracji środowisk gospodarczych. Realizację wspomnianego celu poznawczego przeprowadzono w dwóch normatywnych płaszczyznach badawczych: w obszarze przepisów regulujących działalność i organizację spółdzielni, w tym członkostwo w spółdzielni oraz strukturę jej organów, jako pojedynczego podmiotu (pierwsza płaszczyzna) oraz w sferze rozwiązań odnoszących się do struktur wielopodmiotowych, łączących większą liczbę spółdzielni, takich jak związki spółdzielcze i samorząd spółdzielczy (druga płaszczyzna). Zdecydowana większość rozważań koncentruje się na pierwszej płaszczyźnie badawczej, co znajduje swoje uzasadnienie zarówno w dużo większej obszerności regulacji prawnych związanych z tą pierwszą płaszczyzną, jak również w większym znaczeniu tych przepisów dla obrotu gospodarczego w Polsce.

Oprócz przywołanego wyżej celu poznawczego prezentowane opracowanie ma również cel praktyczny, ściśle zresztą związany z tym pierwszym celem. Celem praktycznym jest sformułowanie pod adresem ustawodawcy postulatów ukierunkowujących przyszłe ustawodawstwo, których realizacja pozwoli spółdzielniom w większym stopniu realizować ich zadania związane $\mathrm{z}$ integracją środowisk gospodarczych.

Można postawić hipotezę, że do ustawy Prawo spółdzielcze zostały włączone przez prawodawcę rozwiązania prawne otwierające spore możliwości integracji środowisk gospodarczych, choć wydaje się, iż istnieją jeszcze pewne luki ustawodawcze, których uzupełnienie jeszcze mocniej będzie sprzyjać konsolidacyjnej funkcji spółdzielczości w odniesieniu do tych środowisk.

Temat opracowania, jak również przedstawione wyżej cele badawcze, determinują przyjęty aparat metodologiczny, który musi być właściwy dla nauk prawnych. Na nieodłączność tego typu relacji zwracał uwagę Stanisław Ehrlich, pisząc: „Związek metody badawczej z przedmiotem badanym jest oczywisty. [...] O ile jednak wybór przedmiotu badań zależy od swobodnej decyzji badacza, to sprawa metody przedstawia się inaczej. Wybór metody wyznacza natomiast przedmiot, ściślej mówiąc, cel badań, jaki sobie stawiamy" (Ehrlich, 1964: 641). Nie wchodząc zbyt głęboko w złożone analizy teoretycznoprawne na temat metodyki stosowanej przez prawników, należy jednak wskazać tę metodę badawczą, która pozwoli najlepiej zrealizować cele niniejszego opracowania. Tą metodą jest metoda dogmatyczna. W pewnym uproszczeniu polega ona na dążeniu do rozstrzygnięcia kwestii o charakterze interpretacyjnym i walidacyjnym z punktu widzenia określonego systemu prawnego (Kowalski, 1986: 29). Oprócz wspomnianych wyżej kwestii dogmatyka m.in. rekomenduje właściwe rozwiązania w przyszłości (Kowalski, 1986: 29). Należy przypomnieć, że wykładnia prawa to - w tradycyjnym ujęciu - ustalanie, jakie jest językowe znaczenie (sens) przepisu prawnego (Borucka-Arctowa, Woleński, 1997: 90). W szczególności w opracowaniu posłużono się wykładnią doktrynalną, stosowaną m.in. właśnie przez dogmatyków (Tobor, 1997: 209).

\section{Przegląd literatury przedmiotu i dotychczas prowadzonych badań}

Dokonany przegląd literatury przedmiotu pozwala stwierdzić, że problematyka spółdzielczości jako formy integracji środowisk gospodarczych, rozważana z perspektywy prawnej, nie była dotychczas przedmiotem analiz. Nie oznacza to oczywiście, że spółdzielczość 
jako taka pozostaje poza obszarem zainteresowań przedstawicieli nauki prawa - jest wręcz przeciwnie. Opracowania dotyczące spółdzielczości są liczne, a ich zakres tematyczny jest szeroki. Co więcej, wyniki analiz przeprowadzonych przez przedstawicieli doktryny, pomimo że założenia badawcze leżące u ich podstaw nie pokrywały się wprost z celami niniejszego artykułu, mogły zostać i zostały wykorzystane w trakcie przygotowywania niniejszego opracowania. Szczegółowe wnioski z tych analiz zaprezentowano w dalszych częściach opracowania przy okazji omawiania poszczególnych regulacji zawartych w ustawie Prawo spółdzielcze. W tym miejscu natomiast zostały wskazane te pozycje literaturowe, które prezentując wspomniane wnioski, pozwoliły tym samym wzbogacić warstwę poznawczą niniejszego opracowania, i które mogą stanowić dla czytelnika źródło pogłębionej wiedzy o zagadnieniach jedynie zasygnalizowanych w prezentowanym artykule $\mathrm{z}$ uwagi na objętościowe ograniczenia tekstu.

Jeżeli chodzi o badania dotyczące prawnej istoty spółdzielni, w tym statusu ich członków, trzeba zwrócić uwagę na analizę dokonaną przez Krzysztofa Pietrzykowskiego, w której autor - konfrontując własności spółdzielni i spółki handlowej - doszedł m.in. do następującego wniosku: stosunek członkostwa zarówno w spółdzielni, jak i w spółkach (z ograniczoną odpowiedzialnością i akcyjnej) ma charakter cywilnoprawny (Pietrzykowski, 1991: 73). W praktyce determinuje to sposób orzekania przez sądy w tego typu sprawach. Zestawienie cech spółki handlowej i spółdzielni, zwłaszcza w aspekcie historycznym, stanowi również przedmiot badań Piotra Bielskiego, w których wskazał on m.in. na rodzajową tożsamość stosunków prawnych spółki handlowej oraz spółdzielni (Bielski, 2010: 58). Fakt ten może być $\mathrm{z}$ powodzeniem wykorzystany $\mathrm{w}$ praktyce obrotu gospodarczego $\mathrm{z}$ udziałem spółek handlowych i spółdzielni. W podobny nurt badań wpisuje się również opracowanie Piotra Zakrzewskiego, w którym autor zestawił ze sobą rozwiązania dotyczące spółdzielni i spółek oraz przedstawił cechy spółdzielni w innych państwach (Zakrzewski, 2004: 121-141). Tego rodzaju badania prawnoporównawcze stanowią bez wątpienia cenne źródło inspiracji dla polskiego prawodawcy. Z kolei do kwestii członkostwa w spółdzielniach nawiązuje również przekrojowe opracowanie Zdzisława Niedbały, w którym autor wyraził m.in. pogląd o niemożności posiadania przez osoby prawne statusu członka w spółdzielni pracy (Niedbała, 2005: 91). Dla praktyki życia gospodarczego oznacza to zawężenie kręgu podmiotów zainteresowanych spółdzielczą formą gospodarowania.

Oddzielny przedmiot badań przedstawicieli doktryny prawniczej stanowi kwestia podziału spółdzielni. To szczególne zagadnienie badawcze było przedmiotem opracowania autorstwa Małgorzaty Wrzołek-Romańczuk, w którym autorka wskazała w szczególności na następstwa płynące $\mathrm{z}$ podziału spółdzielni w aspekcie osobowym i majątkowym (Wrzołek-Romańczuk, 1995: 30-31). Kwestia ta jest istotna dla stabilności stosunków prawnych. Z kolei Krzysztof Stefaniuk m.in. poddał krytyce zbyt liberalne podejście ustawodawcy do warunków podejmowania uchwał (wymagana jest tylko zwykła większość głosów) dotyczących podziału spółdzielni (Stefaniuk, 2001: 118-119). Krytyka ta jest jak najbardziej uzasadniona, gdyż w praktyce gospodarczej takie mało restrykcyjne warunki nie sprzyjają bezpieczeństwu obrotu prawnego. Na koniec trzeba też wspomnieć o obszernym opracowaniu Przemysława Grzesioka, dotykającym szczególnie istotnego z punktu widzenia praktyki obrotu gospodarczego problemu, jakim jest działalność uchwałodawcza organów spółdzielni, w którym to opracowaniu autor przedstawił swoje wnioski na temat cech uchwały organu spółdzielni (Grzesiok, 2005: 186-189). Wnioski te mogą stanowić istotną pomoc dla praktyków zajmujących się prawem spółdzielczym. 
Wspólna działalność gospodarcza spółdzielni i ogólne warunki członkostwa w nich jako narzędzia integracji środowisk gospodarczych

Jednym z najbardziej czytelnych przepisów wskazujących na możliwość integracji przez spółdzielnie środowisk gospodarczych jest art. $1 \$ 1$ ustawy Prawo spółdzielcze deklarujący, że spółdzielnia „prowadzi wspólną działalność gospodarczą”. Ta wspólna działalność gospodarcza stanowi element definicji samej spółdzielni jako szczególnego podmiotu, która to definicja została już przytoczona na wstępie niniejszego artykułu. Warto w tym miejscu zaznaczyć, że także na przykład w Niemczech spółdzielnia kwalifikowana jest jako wyodrębniona forma prawna (inna niż spółka handlowa bądź stowarzyszenie), a w Szwajcarii spółdzielnie są odrębnymi i samodzielnymi formami prawnymi, choć wykazującymi się pewnym podobieństwem do innych struktur organizacyjnych (Zakrzewski, 2004: 121-122, 125). Natomiast przykładowo we Francji spółdzielnie przyjmują formę spółek prawa cywilnego bądź handlowego (Zakrzewski, 2004: 126).

$\mathrm{Na}$ gruncie polskich rozwiązań prawnych rodzi się jednak pytanie, jakie podmioty reprezentujące środowiska gospodarcze mogą być członkami spółdzielni. Odpowiadając na to pytanie w sposób najbardziej ogólny, należy wskazać, że zgodnie z art. $15 \$ 2$ ustawy Prawo spółdzielcze jako członek spółdzielni może występować każdy podmiot, będący osobą fizyczną, cieszący się pełną zdolnością do czynności prawnych i odpowiadający wymogom przewidzianym statutem, przy założeniu, iż ustawa nie zawiera odmiennych uregulowań. Jednakże, o czym stanowi z kolei art. $15 \$ 3$ ustawy Prawo spółdzielcze, w statucie mogą zostać wyszczególnione przypadki, w których członkami spółdzielni mogą być osoby mające jedynie ograniczoną zdolność do czynności prawnych bądź niemające jej wcale, z tym, że osoby takie mają zakaz wchodzenia w skład organów spółdzielni, a uczestnictwo takich osób na walnym zgromadzeniu dopuszczalne jest tylko poprzez ich przedstawicieli ustawowych. Ponadto, jak ujmuje to art. $15 \$ 4$ ustawy Prawo spółdzielcze, w charakterze członków spółdzielni mogą występować także osoby prawne, przy czym uwarunkowane to jest brakiem odmiennych postanowień statutowych. Należy w tym miejscu wyjaśnić, że zgodnie z art. 33 Ustawy z dnia 23 kwietnia 1964 r. Kodeks cywilny (tekst jednolity: Dz.U. z 2019 r., poz. 1145) osobami prawnymi są zarówno Skarb Państwa, jak i te jednostki organizacyjne, dla których przepisy szczególne taką osobowość prawną przewidziały. Oczywiście należy pamiętać, że w każdym przypadku substratem osoby prawnej będzie organizacja ludzka (Radwański, Olejniczak, 2015: 181).

\section{Szczególne kategorie spółdzielni i ich członkowie}

Naturalnie zaprezentowane wyżej przepisy nie wyczerpują kwestii rodzaju środowisk gospodarczych, dla których spółdzielnie mogą być czynnikiem integrującym. Trzeba bowiem pamiętać, że ustawa Prawo spółdzielcze zawiera w ramach części I zatytułowanej Spółdzielnie tytuł II pod nazwą Przepisy szczególne dla spółdzielni produkcji rolnej, spółdzielni kółek rolniczych i spółdzielni pracy (art. 138-art. 203x). Bez względu jednak na szczegółowe rozwiązania, o których szerzej jest mowa niżej, należy zaznaczyć, że każda spółdzielnia uzyskuje osobowość prawną w chwili umieszczenia wpisu o niej w Krajowym Rejestrze Sądowym (art. $11 \$ 1$ ustawy Prawo spółdzielcze). Jak trafnie podkreśla się w literaturze przedmiotu, o bycie prawnym spółdzielni i złączonej z nim zdolności prawnej i zdolności do czynności prawnych można mówić w momencie 
uzyskania osobowości prawnej, a to z kolei następuje po zarejestrowaniu (Trzebiatowski, 2005: 132).

Przechodząc do zasygnalizowanych wyżej przepisów szczególnych, trzeba wspomnieć, że silnie predestynowane do integracji kręgu producentów rolnych są spółdzielnie określane mianem rolniczych spółdzielni produkcyjnych (spółdzielnie te zostały szeroko unormowane w rozdziale 1 zatytułowanym Rolnicze spółdzielnie produkcyjne działu I pod tytułem Spółdzielnie produkcji rolnej, stanowiącego z kolei część wspomnianego wyżej tytułu II omawianej ustawy). Ustawodawca wskazuje bowiem, że w ramach swojego przedmiotu działalności prowadzą one wspólne gospodarstwo rolne oraz działalność na rzecz pojedynczych gospodarstw rolnych należących do ich członków, przy czym nie jest wykluczone prowadzenie przez takie spółdzielnie także innej działalności gospodarczej (art. 138 ustawy Prawo spółdzielcze). W przypadku takich spółdzielni krąg ich potencjalnych członków jest ściśle określony, bowiem mogą go tworzyć rolnicy mający status właściciela lub posiadacza samoistnego gruntów rolnych, dzierżawcy, użytkownika lub innego posiadacza zależnego gruntów rolnych (art. $139 \$ 1$ pkt 1 i 2 ustawy Prawo spółdzielcze).

Z kolei w dziale II zatytułowanym Spółdzielnie kółek rolniczych (usług rolniczych) (art. 180) powołanego wyżej tytułu II ustawy Prawo spółdzielcze, ustawodawca unormował, jak sam tytuł wskazuje, spółdzielnie kółek rolniczych (usług rolniczych). W przypadku tego rodzaju spółdzielni przedmiot ich gospodarczej działalności polega na świadczeniu usług skierowanych do rolnictwa oraz innego rodzaju usług, na które zgłasza zapotrzebowanie środowisko wiejskie (art. $180 \$ 1$ ustawy Prawo spółdzielcze). Dodatkowo, jak wynika $\mathrm{z}$ art. $180 \$ 2$ ustawy Prawo spółdzielcze, taka spółdzielnia może także wytwarzać środki i materiały służące rolnictwu, przetwórstwu rolnemu i produkcji rolnej (prowadzić gospodarstwo rolne). Pod względem kategorii podmiotów, wobec których wspomniane spółdzielnie mogą pełnić funkcję czynnika integrującego, należy zauważyć, że mogą one zrzeszać zarówno osoby prawne, jak i osoby fizyczne, na co wskazuje art. $180 \$ 3$ ustawy Prawo spółdzielcze.

I wreszcie niezwykle interesującymi, a jednocześnie odgrywającymi ważną rolę integracyjną spółdzielniami są spółdzielnie unormowane w dziale III pod nazwą Spółdzielnie pracy (art. 181-art. 203) zamieszczonym we wzmiankowanym już wyżej tytule II ustawy Prawo spółdzielcze. Ogólnie rzecz ujmując, przedmiot działalności gospodarczej takich spółdzielni sprowadza się do prowadzenia wspólnego przedsiębiorstwa, przy czym musi to się opierać na osobistej pracy członków (art. 181 ustawy Prawo spółdzielcze). W kontekście brzmienia tego przepisu podkreśla się, że członkami takich spółdzielni nie mogą być osoby prawne (także wtedy, gdyby w statucie nie było zapisu jednoznacznie wyłączającego takie członkostwo), bowiem w przypadku tego rodzaju spółdzielni spółdzielnia oraz jej członek muszą być nieprzerwanie - w czasie trwania członkostwa - związani stosunkiem pracy, który cechuje się dla pracownika osobistym charakterem, co oznacza, że świadczyć pracę może on tylko osobiście (Niedbała, 2005: 91). Idea, na której opiera się działalność spółdzielni pracy, polega na tym, że podmioty będące jej członkami zarówno zarządzają nią, jak i są jej pracownikami (Zakrzewski, 2005: 79). Jednocześnie wyodrębnione zostały spółdzielnie inwalidów i spółdzielnie niewidomych, które za przedmiot swojej działalności mają zawodową i społeczną rehabilitację inwalidów i osób niewidomych przez wykonywanie pracy w ramach wspólnego przedsiębiorstwa (art. 181a $\$ 1$ ustawy Prawo spółdzielcze). Ponadto, ustawodawca zdecydował się na wyszczególnienie spółdzielni pracy rękodzieła ludowego i artystycznego, które to spółdzielnie mają tworzyć nowe 
i kultywować dawne wartości kultury o charakterze materialnym, organizować i rozwijać rękodzieło ludowe oraz artystyczne, jak również sztukę oraz przemysł artystyczny (art. 181a $\$ 2$ ustawy Prawo spółdzielcze).

Walne zgromadzenie jako element struktury spółdzielni i jego funkcja integrująca środowiska gospodarcze

Kolejnym elementem stymulującym integrację środowisk gospodarczych jest bez wątpienia struktura spółdzielni. W tym przypadku chodzi w szczególności o to, że sam kształt organizacyjny spółdzielni sprzyja integracji i wymianie poglądów pomiędzy członkami spółdzielni. Na temat organów spółdzielni jest mowa przede wszystkim w dziale IV pod tytułem Organy spółdzielni tytułu I (Przepisy wspólne) ustawy Prawo spółdzielcze. Przed bliższą charakterystyką wybranych przepisów tyczących się wspomnianych wyżej kwestii, należy jeszcze wspomnieć o prawnej specyfice spółdzielni. Otóż w doktrynie wskazuje się przede wszystkim na to, że spółdzielnia jest w swej istocie zrzeszeniem osób, pomimo iż poza substratem osobowym, czyli członkami - posiada ona również substrat majątkowy opierający się na własności i innych prawach rzeczowych, prawach obligacyjnych, jak też na prawach na dobrach niematerialnych (Pietrzykowski, 1991: 66). Istota spółdzielni jako zrzeszenia osób oczywiście nie oznacza, że można ją sprowadzić i ograniczyć tylko i wyłącznie do jednej z form zrzeszenia osób. Istota ta wskazuje natomiast, że - jak podkreśla się w doktrynie - istnieje wyraźna relacja podporządkowania stosunkom niemajątkowym, czyli stosunkom członkostwa, stosunków majątkowych zachodzących pomiędzy spółdzielnią a podmiotami będącymi jej członkami (Pietrzykowski, 1991: 66). Warto dodać, że „stosunki prawne spółki handlowej i spółdzielni są stosunkami obligacyjno-organizacyjnymi, które istotnie różnią się od klasycznych stosunków obligacyjnych” (Bielski, 2010: 58).

Wracając do analizy rozwiązań zawartych w rozpatrywanej ustawie, trzeba wspomnieć, że zgodnie z art. $35 \$ 1$ pkt 1-4 ustawy Prawo spółdzielcze, system organów spółdzielni składa się z walnego zgromadzenia, rady nadzorczej, zarządu oraz zebrania grup członkowskich, przy czym zebranie to występuje w tych spółdzielniach, które nie mają walnego zgromadzenia, bowiem zostało ono zastąpione zebraniem przedstawicieli. Dla realizacji celów artykułu zasadne będzie skoncentrowanie się w pierwszej kolejności na funkcjonowaniu walnego zgromadzenia jako tego forum, które najlepiej integruje dane środowisko gospodarcze o nie zawsze jednolitych poglądach.

Przede wszystkim trzeba zaznaczyć, że walne zgromadzenie stanowi najwyższy organ spółdzielni (art. $36 \$ 1$ ustawy Prawo spółdzielcze). Każdemu członkowi przysługuje jeden głos i to niezależnie od tego, ile ma udziałów, przy czym w statucie spółdzielni, która wśród swoich członków może mieć tylko osoby prawne, można sformułować inną regułę wyznaczania liczby głosów przypadających poszczególnym członkom (art. $36 \$ 2$ ustawy Prawo spółdzielcze). Jednak to funkcje realizowane przez walne zgromadzenie, a wyszczególnione w art. $38 \$ 1$ ustawy Prawo spółdzielcze, w sposób najbardziej pełny ukazują integrującą rolę tego organu. Spośród rozlicznych zadań - wskazanych we wspomnianym art. $38 \$ 1$ analizowanej ustawy - walnego zgromadzenia należących do jego wyłącznej kompetencji trzeba wymienić w szczególności: „1) uchwalanie kierunków rozwoju działalności gospodarczej oraz społecznej i kulturalnej; 2) rozpatrywanie sprawozdań rady, zatwierdzanie sprawozdań rocznych i sprawozdań finansowych oraz podejmowanie uchwał co do wniosków członków spółdzielni, rady lub zarządu w tych sprawach i udzielanie absolutorium 
członkom zarządu; [...] 5) podejmowanie uchwał w sprawie zbycia nieruchomości, zbycia zakładu lub innej wyodrębnionej jednostki organizacyjnej; 6) podejmowanie uchwał w sprawie przystępowania do innych organizacji gospodarczych oraz występowania z nich; 8) podejmowanie uchwał w sprawie połączenia się spółdzielni, podziału spółdzielni oraz likwidacji spółdzielni”. Przytoczone wyżej przykłady pokazują, że właściwa i niezakłócona działalność spółdzielni niejako wymusza uprzednią integrację danego środowiska gospodarczego funkcjonującego w ramach tej spółdzielni. Bez integracji trudno byłoby wypracować kompromis niezbędny do podejmowania odpowiednich uchwał. W kontekście tych przykładowych kompetencji walnego zgromadzenia trzeba też zaznaczyć, że członek organu spółdzielni (Grzesiok, 2005: 186) nie może wpływać na podjęcie planowanej uchwały inaczej, jak tylko podczas aktu głosowania (Grzesiok, 2005: 181). Uchwały charakteryzują się po pierwsze tym, że przejawia się w nich wola organu spółdzielni, choć czasami mogą one prezentować określone stanowisko niemające doniosłości normatywnej, ale wyrażające określony rozkład sił w organie spółdzielni. Po drugie, jeżeli zostanie już podjęta jakaś uchwała, to modyfikacji jej postanowień można dokonać w drodze zmiany tej uchwały bądź podjęcia nowej uchwały w tej samej materii z jednoczesnym uchyleniem poprzedniej (Grzesiok, 2005: 187). Uchwała organu spółdzielni (Grzesiok, 2005: 186) w sposób formalnoprawny przejawia wolę tego organu, umożliwia spółdzielni funkcjonowanie i realizowanie wspólnego celu jej członków (Grzesiok, 2005: 203)

Warto jeszcze nieco bliżej przyjrzeć się jednej z wyżej wymienionych funkcji walnego zgromadzenia, mianowicie związanej z podejmowaniem uchwał dotyczących podziału spółdzielni. Wbrew pozorom, podjęcie takiej uchwały może w istocie sprzyjać większej integracji środowisk gospodarczych. Teza ta znajduje potwierdzenie w regulacji zawartej w art. 108a $\$ 1$ zdanie pierwsze ustawy Prawo spółdzielcze, zgodnie z którą podmioty będące członkami „spółdzielni, których prawa i obowiązki majątkowe są związane z wyodrębnioną organizacyjnie jednostką spółdzielni albo z częścią majątku spółdzielni, która nadaje się do takiego wyodrębnienia, mogą na podstawie uchwały podjętej większością głosów tych członków wystąpić do zarządu spółdzielni z żądaniem zwołania walnego zgromadzenia w celu podjęcia uchwały o podziale spółdzielni w ten sposób, że z tej jednostki organizacyjnej albo części majątku zostanie utworzona nowa spółdzielnia”. Na podstawie tego przepisu określony krąg członków spółdzielni może - właśnie celem ściślejszej integracji - podjąć kroki w kierunku utworzenia własnej organizacji lepiej realizującej jego interesy. Ważne jest przy tym, że już w strukturze dzielonej spółdzielni jej członkowie muszą charakteryzować się posiadaniem uprawnień i obowiązków majątkowych mających wspólny mianownik w postaci związku z daną jednostką organizacyjną bądź częścią majątku spółdzielczego.

Dodać należy, że istnieje możliwość podziału spółdzielni na podstawie uchwały walnego zgromadzenia podjętą zwykłą większością głosów, przy czym podział taki polega na tym, że tworzy się nową spółdzielnię z wydzielonej z niej części (art. $108 \$ 1$ ustawy Prawo spółdzielcze). Przepis ten wymaga komentarza. Otóż należy podkreślić, że skutkiem podziału jest utworzenie nowego podmiotu posiadającego osobowość prawną (ewentualnie podmiotów o statusie osób prawnych) oraz zmiany w substracie osobowym i majątkowym spółdzielni dzielonej (Wrzołek-Romańczuk, 1995: 30). Nie sposób jednak pominąć faktu, że - jak podkreśla się w literaturze - zgodnie z powyższym przepisem podział spółdzielni został potraktowany jak typowa sprawa, do rozstrzygnięcia której wystarczy zwykła większość głosów, co jest dość kontrowersyjne (Stefaniuk, 2001: 118). 
Inne organy spółdzielni i ich rola w integracji środowisk gospodarczych

Na zakończenie omawiania kwestii struktury spółdzielni należy jeszcze krótko scharakteryzować inne organy, to jest: radę nadzorczą, zarząd oraz zebrania grup członkowskich (zob. art. $35 \$ 1$ pkt 2-4 ustawy Prawo spółdzielcze). Kompetencją rady nadzorczej jest kontrolowanie i nadzorowanie działalności spółdzielni (art. 44 ustawy Prawo spółdzielcze). W art. $45 \$ 1$ ustawy Prawo spółdzielcze ustawodawca zadeklarował, że w skład rady wchodzi przynajmniej trzech członków. Jeżeli chodzi o bardziej szczegółowe kompetencje rady nadzorczej, to trzeba tutaj wskazać przede wszystkim to, że uchwala ona plany gospodarcze i programy działalności o charakterze społecznym i kulturalnym, podejmuje uchwały związane z nabyciem i obciążeniem nieruchomości oraz nabyciem zakładu bądź innej struktury organizacyjnej, jak również uchwały dotyczące przystąpienia do organizacji o charakterze społecznym i występowania $\mathrm{z}$ takich podmiotów (art. $46 \$ 1$ pkt 1, 3, 4 ustawy Prawo spółdzielcze). Z kolei zarząd to organ zajmujący się kierowaniem działalnością spółdzielni i reprezentowaniem jej na zewnątrz, przy czym wszelkie decyzje niezastrzeżone w ustawie bądź statucie dla innych organów podejmowane są przez zarząd (art. $48 \$ 1$ i $\$ 2$ ustawy Prawo spółdzielcze). Trzeba jeszcze zaznaczyć, że do materii statutowej należy określenie składu i liczby członków zarządu, przy czym w statucie można wskazać, że zarząd będzie jednoosobowy (zob. art. $49 \$ 1$ ustawy Prawo spółdzielcze). I wreszcie, w spółdzielniach, które zamiast walnego zgromadzenia mają zebranie przedstawicieli (ustawodawca czyni tutaj jednak zastrzeżenie związane z treścią art. $8^{3}$ Ustawy $z$ dnia 15 grudnia 2000 r. o spółdzielniach mieszkaniowych), do organów takich spółdzielni zalicza się również zebrania grup członkowskich (art. $59 \$ 1$ zdanie pierwsze ustawy Prawo spółdzielcze). Takie zebrania zajmują się m.in. rozpatrywaniem okresowych sprawozdań składanych przez radę i zarząd, jak również wyrażaniem swojej opinii oraz zgłaszaniem właściwym organom spółdzielni wniosków w sprawach spółdzielczych, w szczególności w sprawach wspólnych dla członków należących do zebrania grupy (art. $59 \$ 2$ pkt 4 i 5 ustawy Prawo spółdzielcze).

Podkreśla się w literaturze przedmiotu, że kolegialność organów spółdzielni jest zasadą i wskazuje w szczególności, iż walne zgromadzenie i zebrania grup członkowskich z samej swojej definicji nie mogą być monokratyczne, a rada nadzorcza nie może mieć mniej niż trzech członków, przy czym z kolei w odniesieniu do zarządu podkreśla się, że może on być wprawdzie jednoosobowy, ale jest to sytuacja wyjątkowa, a nie zasada (Grzesiok, 2005: 170-171). Integracyjna rola organów spółdzielni znajduje wyraz właśnie w ich kolegialności. Łatwo można zauważyć, mając na względzie wagę kompetencji przyznanych poszczególnym organom, że bez współdziałania między poszczególnym członkami danych organów spółdzielczych bardzo szybko nastąpiłby paraliż funkcjonowania tych organizacji.

Związki spółdzielcze i samorząd spółdzielczy jako czynniki integrujące środowiska gospodarcze

Ważne znaczenie dla integracyjnej roli spółdzielczości ma również określona w ustawie Prawo spółdzielcze działalność związków spółdzielczych oraz samorządu spółdzielczego. Jeżeli chodzi o związki spółdzielcze, to kwestia ta została unormowana w tytule I pod nazwą Związki spółdzielcze (art. 240-257) umieszczonym w części II pt. Związki spółdzielcze 
i Krajowa Rada Spółdzielcza. Natomiast funkcjonowanie samorządu spółdzielczego ustawodawca uregulował w tytule II pod nazwą Krajowy samorząd spółdzielczy (art. 358-267), występującym także we wspomnianej wyżej części II ustawy Prawo spółdzielcze.

W odniesieniu do związków spółdzielczych ustawodawca zadeklarował, że spółdzielnie mają prawo zakładania związków rewizyjnych i przystępowania do nich, przy czym dla każdego związku rewizyjnego minimalna liczba założycieli wynosi dziesięciu (art. $240 \$ 1$ ustawy Prawo spółdzielcze). Cel wspomnianego związku polega na udzielaniu skonsolidowanym w jego ramach spółdzielniom wsparcia w prowadzonej przez nie działalności statutowej (art. $240 \$ 2$ ustawy Prawo spółdzielcze). Jeżeli natomiast chodzi o zadania związku rewizyjnego, to polegają one na przeprowadzaniu lustracji w stosunku do zrzeszonych spółdzielni, prowadzeniu na ich rzecz działalności o charakterze instruktażowym, doradczym, kulturalno-oświatowym, szkoleniowym i wydawniczym, reprezentowaniu interesów tych spółdzielni w relacjach $\mathrm{z}$ organami administracji państwowej oraz organami samorządu terytorialnego, reprezentowaniu zrzeszonych spółdzielni poza granicami kraju, inicjowaniu i rozwijaniu kooperacji pomiędzy spółdzielniami oraz współpraca $\mathrm{z}$ instytucjami naukowo-badawczymi, wykonywaniu innych zadań ujętych ustawą Prawo spółdzielcze bądź statutem (art. $240 \$ 3$ pkt 1-6 ustawy Prawo spółdzielcze). Trzeba również wspomnieć, że spółdzielnie mogą być założycielami związków gospodarczych i mogą przystępować do nich (art. $243 \$ 1$ ustawy Prawo spółdzielcze). Cel takich związków to "prowadzenie działalności gospodarczej na rzecz lub w interesie zrzeszonych spółdzielni” (art. $243 \$ 2$ ustawy Prawo spółdzielcze).

Natomiast w kwestii integracyjnej roli samorządu spółdzielczego należy w pierwszej kolejności wyodrębnić zwoływany raz na cztery lata Kongres Spółdzielczości traktowany jako najwyższy organ samorządu spółdzielczego (art. $258 \$ 1$ ustawy Prawo spółdzielcze). Ocenia on stan spółdzielczości w Polsce, jak też warunki i szanse jej rozwoju, a ponadto podejmuje uchwałę ustalającą statut Krajowej Rady Spółdzielczości i reguły, na jakich organizacje spółdzielcze finansują jej działalność oraz wybiera członków Rady, określając jednocześnie zasady ich odwoływania (art. 258a ustawy Prawo spółdzielcze). O ile powyższe funkcje Kongresu Spółdzielczości są niewątpliwie bardzo istotne, o tyle z punktu widzenia procesów integracyjnych środowiska gospodarczego zasadniczą rolę należy przypisać Krajowej Radzie Spółdzielczej. Stanowi ona naczelny organ samorządu spółdzielczego (art. $259 \$ 1$ ustawy Prawo spółdzielcze). Integrująca rola Krajowej Rady Spółdzielczości wyraża się przede wszystkim w tym, że reprezentuje ona polski ruch spółdzielczy w kraju oraz poza jego granicami, współdziała z różnymi naczelnymi organami państwa w sprawach powiązanych z ruchem spółdzielczym, bada i ocenia formy, warunki, kierunki oraz wyniki działań ruchu spółdzielczego oraz kieruje informacje i wnioski do naczelnych organów państwowych, organizuje działalność naukowo-badawczą, szkoleniową i informacyjną, propaguje działalność kulturalno-oświatową członków, podejmuje inicjatywy ukierunkowane na rozwój krajowego ruchu spółdzielczego (włączając w to spółdzielczość uczniowską), kształtuje warunki pomocne w rozwoju ruchu spółdzielczego, inicjuje i rozwija współpracę międzyspółdzielczą i szerzy ideę spółdzielczego współdziałania (art. $259 \$ 2$ pkt 1, 2, 4-6 ustawy Prawo spółdzielcze).

Podsumowując tę część rozważań warto zaakcentować, że związki spółdzielcze oraz samorząd spółdzielczy mają instrumenty pozwalające na integrację środowisk gospodarczych zrzeszonych przede wszystkim w różnych spółdzielniach. Jest to bardzo istotne, ponieważ ułatwia upowszechnienie myśli i poglądów w szerokich kręgach działaczy 
spółdzielczych, choć należy zadać sobie pytanie, w jakim stopniu te związki i samorząd faktycznie wykorzystują te instrumenty.

\section{Zakończenie}

Podsumowując wyniki przeprowadzonych analiz ukierunkowanych na realizację wytyczonych na wstępie celów badawczych, trzeba stwierdzić, że spółdzielczość można z pewnością traktować jako prawną formę integracji środowisk gospodarczych. Odnosząc się natomiast szczegółowo do wyznaczonego na wstępie opracowania celu poznawczego, należy wskazać, że przepisy ustawy Prawo spółdzielcze zawierają szereg rozwiązań ułatwiających konsolidację tych środowisk przez podmioty spółdzielcze. Realizacja tego celu na płaszczyźnie badawczej związanej z grupą przepisów normujących funkcjonowanie i strukturę spółdzielni pozwala na sformułowanie poniższych wniosków.

Kluczowym przepisem pozwalającym na traktowanie spółdzielni jako podmiotów integrujących środowiska gospodarcze jest art. $1 \$ 1$ ustawy Prawo spółdzielcze stanowiący o prowadzeniu przez spółdzielnie wspólnej działalności gospodarczej w interesie jej członków. Tym samym ustawodawca ukształtował spółdzielnie jako podmioty ukierunkowane właśnie na prowadzenie takiej działalności. Prawodawca nie ograniczył się jednak do wprowadzenia powyższej normy, ale wpisał do rzeczonej ustawy szereg regulacji stanowiących ramy organizacyjne dla integracji przedstawicieli poszczególnych środowisk gospodarczych, zwłaszcza producentów rolnych. Wyrazem tego są przepisy tytułu II pod nazwą Przepisy szczególne dla spółdzielni produkcji rolnej, spółdzielni kółek rolniczych i spółdzielni pracy (art. 138-203x) zamieszczonego w części I zatytułowanej Spółdzielnie.

Kolejny zespół norm, który niewątpliwie sprzyja integracyjnej roli spółdzielczości, to regulacje związane ze strukturą organizacyjną spółdzielni. W ramach rozważań zaprezentowane zostały podstawowe przepisy dotyczące organów spółdzielni, tj. walnego zgromadzenia, rady nadzorczej, zarządu oraz zebrań grup członkowskich (zob. art. $35 \$ 1$ pkt 1-4 ustawy Prawo spółdzielcze). Podkreślana w literaturze przedmiotu zasada kolegialnego charakteru organów spółdzielni (Grzesiok, 2005: 170) jest szczególnie istotna z punktu widzenia możliwości integracyjnego odziaływania spółdzielni. Takie ukształtowanie struktury organów siłą rzeczy wymusza konsolidację ich członków, tak aby możliwe było wypracowanie wspólnego stanowiska w kwestiach związanych z działalnością spółdzielni.

Spółdzielczość pomaga w integracji środowisk gospodarczych również poprzez działalność związków spółdzielczych i samorządu spółdzielczego. Analiza regulacji w ramach tej drugiej płaszczyzny badawczej, nawiązującej do struktur wielopodmiotowych, ukazała konkretne kompetencje prawne, które mogą temu służyć, jak choćby wyszczególnione w opracowaniu zadanie związku rewizyjnego polegające na prowadzeniu dla zrzeszonych spółdzielni działań o charakterze instruktażowym, doradczym, kulturalno-oświatowym, szkoleniowym i wydawniczym (art. $240 \$ 3$ pkt 2 ustawy Prawo spółdzielcze).

Przeprowadzone rozważania pozwoliły również zrealizować cel praktyczny opracowania, którym jest sformułowanie pod adresem ustawodawcy postulatów prawodawczych w zakresie spółdzielczości. Te wskazania dotyczące dalszej polityki ustawodawczej w kwestii spółdzielczości mają umożliwić spółdzielniom większą efektywność w urzeczywistnieniu ich roli jako czynnika integrującego środowiska gospodarcze. W pierwszej kolejności należy postulować wprowadzenie do ustawy Prawo spółdzielcze nowych kategorii spółdzielni obejmujących swoim zasięgiem kolejne środowiska gospodarcze. 
Naturalnie taką zmianę ustawodawczą należałoby poprzedzić odpowiednimi badaniami wśród ewentualnych, przyszłych spółdzielców, które dałyby odpowiedź na pytanie, jakie środowiska byłyby zainteresowane taką formą ich konsolidacji. Ponadto, ustawowe rozwiązania prawne dotyczące struktury wewnętrznej spółdzielni nie są doskonałe, bowiem powinny zawierać też unormowania służące wypracowywaniu takich uchwał na forum poszczególnych organów, których treść byłaby możliwie zbieżna z interesem wszystkich członków spółdzielni. Przykładem takiego unormowania mógłby być ustawowy obowiązek zasięgania opinii określonych ekspertów w sytuacji silnego sporu dotyczącego treści uchwały o istotnym znaczeniu dla funkcjonowania spółdzielni. Wydaje się również, że aktualnie obowiązujące regulacje dotyczące związków spółdzielczych i samorządu spółdzielczego są dość lakoniczne i choć zawierają instrumenty sprzyjające integracji środowisk gospodarczych, to jednak - jak zaznaczono wyżej - rodzi się pytanie, w jakim stopniu instrumenty te są wykorzystywane w praktyce. Dlatego należy postulować takie zmiany ustawodawcze, które w sposób bardziej zdecydowany wymuszą na związkach i samorządzie praktyczne wykorzystanie tych instrumentów.

Przeprowadzone w niniejszym artykule rozważania, stanowiące realizację założonych celów badawczych, potwierdzają słuszność wskazanej na wstępie hipotezy badawczej o sporych możliwościach integracji środowisk gospodarczych, które to możliwości mają swoje źródło w regulacjach ustawy Prawo spółdzielcze. Słuszna okazała się również druga część hipotezy, zgodnie z którą aktualnie obowiązujące rozwiązania ustawowe nie są wolne od luk, które należy wypełnić w celu wzmocnienia integracyjnej roli spółdzielczości wobec środowisk gospodarczych.

Należy dodać, że analiza roli spółdzielczości jako czynnika integrującego środowiska gospodarcze prowadzona $z$ perspektywy prawnej napotyka na pewne ograniczenia badawcze. Wynikają one $\mathrm{z}$ dwóch przyczyn. Pierwsza bariera związana jest $\mathrm{z}$ samą metodologią prawniczą. Otóż z całą pewnością analiza przepisów prawa ukierunkowana na wydobycie z nich rozwiązań prawnych sprzyjających integracji gospodarczej niesie z sobą istotną wartość poznawczą, jednak wydaje się, iż wartość ta mogłaby być większa w przypadku uzupełniającego zastosowania w ramach tej analizy technik badawczych pozwalających na weryfikację - zwłaszcza w długim okresie - efektów przyjętych rozwiązań prawnych. Niestety, koszty i długotrwałość takich badań wydają się czynnikami, które zniechęcają badaczy do ich podjęcia na szerszą skalę. Drugie ograniczenie badawcze związane jest z brakiem opracowań prawniczych, które podejmowałyby problem roli spółdzielczości $\mathrm{w}$ integracji środowisk gospodarczych. Tym samym zaproponowany w niniejszym artykule przedmiot badań znajduje się na zupełnie początkowym etapie rozwoju, niemniej jednak można mieć nadzieję, że prezentowane opracowanie zapoczątkuje szersze zainteresowanie tą problematyką w środowiskach prawniczych.

Wydaje się, że dalsze kierunki badań prawnych powinny być zorientowane przede wszystkim na integrującą rolę spółdzielczości w aspekcie globalnym, by w ich efekcie możliwe było rozwijanie rozwiązań prawnych sprzyjających takiej ogólnoświatowej integracji. Niewątpliwie w warunkach globalizującej się gospodarki, w której przedsiębiorcy $\mathrm{z}$ różnych kontynentów, chcąc przetrwać na coraz bardziej konkurencyjnym rynku, muszą łączyć się w większe struktury, spółdzielnie również powinny odgrywać coraz istotniejszą rolę jako czynnik integrujący rozproszone środowiska gospodarcze. Tym samym ogromny potencjał spółdzielczości jako prawnej formy konsolidującej te środowiska będzie mógł zostać wykorzystany w jeszcze większym stopniu. 
Akty prawne i literatura

Legal acts and references

Ustawa z dnia 23 kwietnia 1964 r. Kodeks cywilny (tekst jednolity: Dz.U. z 2019 r., poz. 1145).

Ustawa z dnia 16 września 1982 r. Prawo spółdzielcze (tekst jednolity: Dz.U. z 2018 r., poz. 1285 z późn. $\mathrm{zm}$.).

Ustawa z dnia 6 marca 2018 r. Prawo przedsiębiorców (Dz.U. z 2019 r., poz. 1292).

Bielski, P. (2010). Zasady stosowania kodeksu cywilnego w sprawach ze stosunków prawnych spółki handlowej i spółdzielni (cz. 1). Prawo Spótek, 9, 58-67.

Borucka-Arctowa, M., Woleński, J. (1997). Wstęp do prawoznawstwa. Kraków: Wydawnictwo Uniwersytetu Jagiellońskiego.

Grzesiok, P. (2005). Pojęcie i charakter prawny uchwały organu spółdzielni. Kwartalnik Prawa Prywatnego, 1, 165-215.

Ehrlich, S. (1964). Kilka uwag w sprawie metodologii nauk prawnych. Państwo i Prawo, 11, 641-653.

Kowalski, J. (1986). W: J. Kowalski, W. Lamentowicz, P. Winczorek, Teoria państwa i prawa. Warszawa: Państwowe Wydawnictwo Naukowe.

Kuniewicz, K. (1995). Kilka uwag o nowelizacji prawa spółdzielczego. Radca Prawny, 1, 26-29.

Niedbała, Z. (2005). Spółdzielnie osób prawnych i niektóre szczególne rodzaje spółdzielni w świetle obowiązującej i projektowanej ustawy. Ruch Prawniczy, Ekonomiczny i Socjologiczny, 3, 91-104.

Pietrzykowski, K. (1991). Spółdzielnia a spółka handlowa (I). Przeglad Ustawodawstwa Gospodarczego, 6, 65-73.

Radwański, Z., Olejniczak, A. (2015). Prawo cywilne - częśc ogólna. Warszawa: Wydawnictwo C.H. Beck. Stefaniuk, K. (2001). Podział spółdzielni (zmiany wprowadzone ustawą o spółdzielniach mieszkaniowych). Rejent, 9, 117-127.

Tobor, Z. (1997). W: J. Nowacki, Z. Tobor. Wstęp do prawoznawstwa. Katowice: Naukowa Oficyna Wydawnicza.

Trzebiatowski, M. (2005). Sytuacja prawna spółdzielni przed rejestracją (z uwzględnieniem stowarzyszenia i fundacji przed rejestracją). Kwartalnik Prawa Prywatnego, 1, 93-164.

Wrzołek-Romańczuk, M. (1995). Podział spółdzielni. Palestra, 11/12, 26-32.

Zakrzewski, P. (2005). Cel spółdzielni. Kwartalnik Prawa Prywatnego, 1, 49-91.

Zakrzewski, P. (2004). Z zagadnień konstrukcji prawnej spółdzielni. Rejent, 9, 121-141.

Paweł Marek Woroniecki, dr nauk prawnych, Uniwersytet Jagielloński w Krakowie, Wydział Prawa i Administracji, Katedra Polityki Gospodarczej. Autor w ramach swojej aktywności naukowej analizuje rozwiązania prawne z zakresu finansów publicznych (państwowych i samorządowych), regulacje związane z funkcjonowaniem przedsiębiorców w systemie gospodarczym, a zwłaszcza ich sytuację prawną oraz normatywne podstawy działalności administracji publicznej.

Paweł Marek Woroniecki, doctor of legal sciences, the Jagiellonian University, Faculty of Law and Administration, Chair of Economic Policy. Author within his research activity analyses legal solutions in the field of public finances (governmental and local government), regulations connected with functioning of entrepreneurs in economic system, particularly their legal situation, and normative grounds of public administration's activity.

ORCID: 0000-0002-0352-1042

\section{Adres/Address:}

Uniwersytet Jagielloński w Krakowie

Wydział Prawa i Administracji

Katedra Polityki Gospodarczej

ul. Bracka 12

31-005 Kraków, Polska

e-mail: pawel.woroniecki@uj.edu.pl 